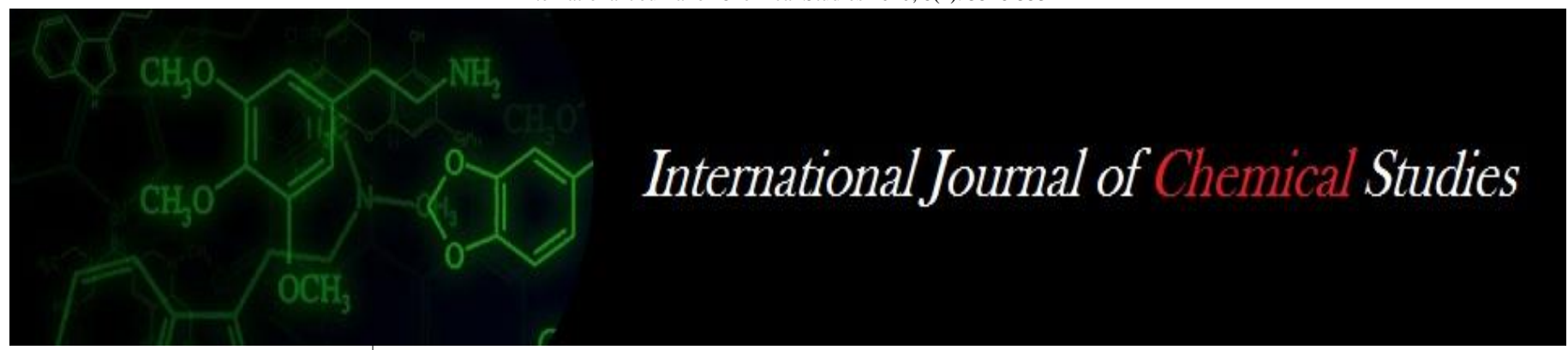

P-ISSN: 2349-8528

E-ISSN: 2321-4902

www.chemijournal.com

IJCS 2020; 8(4): 3528-3531

(C) 2020 IJCS

Received: 12-05-2020

Accepted: 25-06-2020

\section{Thiruppathi M}

Department of Horticulture,

Faculty of Agriculture,

Annamalai University,

Annamalai Nagar, Tamil Nadu, India

\section{S Mullaimaran}

Department of Horticulture,

Faculty of Agriculture,

Annamalai University,

Annamalai Nagar, Tamil Nadu,

India
Corresponding Author:

\section{Thiruppathi M}

Department of Horticulture,

Faculty of Agriculture,

Annamalai University,

Annamalai Nagar, Tamil Nadu,

India

\title{
Effect of seed treatments on germination, growth and vigour of papaya (Carica papaya L.) cv. red lady
}

Thiruppathi M and S Mullaimaran

DOI: https://doi.org/10.22271/chemi.2020.v8.i4ar.10199

\section{Abstract}

The experiment on "Effect of seed treatments on germination, growth and vigour of Papaya (Carica papaya L.)" was carried out at Karimangalam, Dharmapuri district. The experiment was conducted in Completely Randomized Design (CRD) with ten treatments in three replications. The treatments comprised of using water, hot water $\left(60^{\circ} \mathrm{C}\right)$, growth regulators like IBA and GA3 with concentrations of 100 and 500 ppm, respectively, chemicals such as thiourea and $\mathrm{KNO}_{3}$ both with the concentration of $1 \%$ and bio-regulators such as vermiwash (20\%), panchagavya $(3 \%)$ and cow dung slurry. The Papaya fruit seeds were dipped in the hot water for 2 minutes, growth regulators and chemicals for 10 minutes and in water and bio-regulators for 24 hours. Then the seeds were planted in the polybags and kept in the area covered with shade net. The result of the above experiment revealed that the germination parameters viz., germination percentage $(96.10 \%)$, days taken for initial germination (5.60 days) were recorded best in the pre-treatment of $1 \% \mathrm{KNO}_{3}\left(\mathrm{~T}_{5}\right)$. The various growth parameters such viz., number of leaves (10.56), stem girth $(3.45 \mathrm{~mm})$, seedling height $(21.43 \mathrm{~cm})$, root length $(9.20 \mathrm{~cm})$, number of lateral roots $(14.24)$, fresh weight of seedling $(5.02 \mathrm{~g})$, and survival percentage $(93.15 \%)$ were also observed highest in the pretreatment of $1 \% \mathrm{KNO}_{3}$ (T5). The seedling vigour were also found to be maximum in the pretreatment of $1 \% \mathrm{KNO}_{3}\left(\mathrm{~T}_{5}\right)$. The least germination, growth and vigour parameters were observed under control $\left(\mathrm{T}_{10}\right)$. Hence, from the above experiment, it can be concluded that the chemical KNO3@1\% concentration performed best based on the germination, growth and vigour parameters when compared to other treatments.

Keywords: Papaya, seed, germination, growth, growth regulators and $\mathrm{KNO}_{3}$

\section{Introduction}

Papaya (Carica papaya L.) is 7th important fruit crop of the country after Mango, Citrus, Banana, Apple, Guava and Sapota. It is also known as wonder fruits of the tropics. It belongs to the family Caricaceae and is native of Tropical America. It was introduced into India in the 16th century. The fruit is extensively grown in various states of India, mainly in Andhra Pradesh, Gujarat, Karnataka, Madhya Pradesh, Maharashtra, West Bengal, Chhattisgarh, Tamil Nadu, Assam, and Kerala. It gives higher production of fruits per hectare and income next to banana. The total cultivated area of papaya in India is 143 thousand hectares with an annual production of 5980 thousand MT (Anon NHB 2018-19). Propagation of papaya is only through seeds as a viable option. Seed germination in Papaya is very slow, erratic and also incomplete (Chacko and Singh, 1966) ${ }^{[6]}$. The cost of Papaya seed is also high so increasing germination percentage and producing more vigour seedling is a challenge of Papaya grower. The slow germination of papaya seed is due to the presence of some inhibitors like phenolic compound. Seed treatment is required to promote seed germination and reduce the germination time with suitable growth regulators. Gibberellic acid $\left(\mathrm{GA}_{3}\right)$ can stimulate rapid stem and root growth, induce mitotic division in the leaves of some plants, and increase seed germination rate. Growing Media is a substrate that provides the required elements and physical support to the growing plants. While this sarcotesta is reported to prevent germination (Yahiro, 1979) ${ }^{[17]}$. The seeds of papaya are enclosed within a gelatinous sarcotesta (aril, or outer seed coat which is formed from the outer integument.) which can prevent germination (Reyes et al., 1980) ${ }^{[15]}$. Before sowing of seeds is soaking in water or water soluable endogenous hormones has been reported to promote the germination. 
The objective of the study was to increase the seed germination and physiological development of papaya seedlings through applying the growth regulator with growing media and to know the role of different chemicals on seed germination and subsequent seedling vigour.

\section{Materials and Method}

The present investigation on "Effect of seed treatments on germination, growth and vigour of Papaya (Carica papaya L.) cv. Red lady" was conducted at Karimangalam located in Dharmapuri district, Tamil Nadu. The experiment was laid out in a Completely Randomized Design with ten treatment combinations and replicated thrice. Fully mature and healthy fruits of papaya cv. Red lady were collected. Seeds were extracted and shade drying till the seed were completely dried. These fresh seed were collected and subjected to different pre-sowing treatments. The experiment was comprised of ten treatments namely $\mathrm{T} 1$ - Water soaking (24 hours), T2 - Hot water treatment $-60{ }^{\circ} \mathrm{C}$ ( 2 minutes), T3 GA3 -500 ppm (10 minutes) T4 - IBA - 200 ppm (10 minutes), T5 - KNO3 -1\% (10 minutes), T6 - Thiourea $-1 \%$ (10 minutes), T7 - Vermiwash -20\% (24 hours), T8 Panchagavya -3\% (24 hours), T9 - Cow dung slurry (24 hours), T10 - Control. The seed sowing was done in the month of February about $2 \mathrm{~cm}$ depth in polybags filled with coirpith. The polybags were irrigated immediately after seed sowing and repeated every day till the final emergence and kept under shade net. Observations were recorded in respect to first germination from the date of sowing up to germination of the first seedling, seedling height $(\mathrm{cm})$, root length $(\mathrm{cm})$, no. of lateral roots, stem girth $(\mathrm{mm})$, total fresh weight of seedling $(\mathrm{g})$, germination percentage at 45 DAS by counting number of papaya seeds germinated out of total seed dibbled. Seed vigour index at 45 DAS (germination percentage $X$ length of seedlings). The recorded data were analyzed statistically using various techniques as described by Panse and Sukhatme (1985) ${ }^{[12]}$. The treatment means were compared with C.D. at 5 per cent level.

\section{Result and Discussion}

The results showed that pre-soaking chemicals had beneficial effect on seed germination and growth of papaya seedling.

\section{Effect on seed germination parameters}

The treatments have directly influenced the germination of seeds. The highest germination and survival percentage $(93.15 \%)$ was noticed in treated seeds compared to control $(77.30 \%)$. Seeds treated with $1 \% \mathrm{KNO}_{3}$ for 10 minutes (T5) gave highest germination $(96.10 \%)$ when compared to the other treatments (Table 1). Papaya seeds treated with $1 \%$ KNO3 for 10 minutes improves germination. Potassium nitrate stimulates germination at lower concentrations whereas it inhibits at higher concentrations. $\mathrm{GA}_{3}$ also plays an important role in leaching out of the inhibitors which in turn helps in breaking the seed dormancy. The compounds such as nitrate and nitrite stimulate the germination of seeds (Mayer and Poljakoff-Mayber., 1989) ${ }^{[11]}$. Soaking seeds in increased concentration of $\mathrm{KNO}_{3}$ for a shorter duration has increased the germination. Since long time potassium nitrate has been a known suitable chemical used for stimulating germination in many plant species and also used as a priming agent in germination media (Rezvani et al., 2014) ${ }^{[16]}$. The above results are conformity with Anburani and Shakila (2010) ${ }^{[2]}$ in papaya. The hormonal balancing of seeds with germination inhibitors like ABA (abscisic acid) is the positive effect of
$\mathrm{KNO}_{3}$ (Farajollahi et al., 2014). Also less number of days for required of germination (5.60 DAS) as compared to control which has taken 11.26 days for germination. This results were attained due to $\mathrm{KNo}_{3}$ having stimulatory effect in the formation of enzymes which are important in the early phase of germination which helps for faster radicle protrusion. Similar result was reported by Dwivedi et al. (2015) ${ }^{[8]}$ in Carica papaya L. treated with $\mathrm{KNO}_{3}$ resulted in better germination and seedling growth. Further, the result are in close conformity with the findings of Gao et al. (2011) ${ }^{[9]}$ who reported that soaking of oriental lilly seeds in $1 \% \mathrm{KNO}_{3}$ gave the highest germination percentage.

\section{Effect on growth parameters}

The growth parameters of papaya as affected by pre-soaking chemicals are presented in Table (2 and 3). The plant height is one of the important characters in growth and development of seedling. At 45 DAS seeds treated with $\mathrm{KNO}_{3}$ at $1 \%\left(\mathrm{~T}_{5}\right)$ recorded highest height $(21.43 \mathrm{~cm})$ followed by $\mathrm{GA}_{3} 500 \mathrm{ppm}$ $\left(\mathrm{T}_{3}\right)(20.21 \mathrm{~cm})$ as compared to control which had recorded the lowest $(9.15 \mathrm{~cm})$. Prasad (1993) ${ }^{[13]}$ reported that seeds treated with $1 \% \mathrm{KNO} 3$ and $0.5 \%$ recorded maximum plant height and seedling vigour in sorghum and maize. Maximum number of leaves per seedling (10.56) was obtained at the $1 \%$ $\mathrm{KNO}_{3}$ for 10 minutes (T5). The minimum number of leaves per seedling (4.72) was noticed in control. From the physiological point of view, leaf is the most important photosynthetic site of the plant. It is the source from which the plant derives energy for its metabolic activities. The primary function of leaves is the carbon assimilation. The results are in close conformity with Babu (1992) ${ }^{[5]}$ who reported that an increase in the number of leaves was observed due to KNO3 treatment.

Girth at collar region is an important factor for giving the support to seedling at initial stage which is a vital character in health of the seedling. At 45 DAS the seeds treated with $\mathrm{KNO}_{3}$ at $1 \%\left(\mathrm{~T}_{5}\right)$ recorded the highest girth $(3.45 \mathrm{~mm})$ which was on par with seeds treated with 500 ppm of GA3 (3.28 $\mathrm{mm}$ ). The maximum stem girth in case of seedlings obtained from $\mathrm{KNO}_{3}$ and $\mathrm{GA}_{3}$ pre-soaked seeds might be due to the fact that GA3 application enhanced the rate of cell division and elongation of stem portion (Arjun et al., 2017) ${ }^{[4]}$. Increase in stem girth may be possible due to stimulation of cambium and its immediate cell progeny as observed by Dhankhar and Singh (1996) ${ }^{[7]}$ in aonla.

Regarding to length of tap root, seeds treated with $\left(\mathrm{T}_{1}\right) \mathrm{KNO}_{3}$ at $1 \% \mathrm{ppm}$ recorded the highest $(9.20 \mathrm{~cm})$ root length as compared to control $(3.90 \mathrm{~cm})$. The maximum root length might be due to elongation of the cells in the sub-apical region of roots as reported by Arjun et al., $2017^{\text {[4]. The }}$ number of lateral roots per plant, $\mathrm{KNO}_{3}$ at $1 \%\left(\mathrm{~T}_{5}\right)$ treated seeds recorded the highest (14.24) which was on par with seeds treated with $\mathrm{T}_{3}\left(\mathrm{GA}_{3}\right)$ at $500 \mathrm{ppm}$ (31.93). Similar results were also reported by Purbey and Meghwal (2005) ${ }^{[14]}$ when Emblica officinalis seeds were treated with $1 \% \mathrm{KNO}_{3}$ for 18 hours which gave the maximum root length. The fresh weight of shoot, it was highest in seeds treated with $\mathrm{KNO}_{3}$ at $1 \%\left(\mathrm{~T}_{5}\right)(5.02 \mathrm{~g})$ which was at par with seeds treated with $\mathrm{GA}_{3}$ at $500 \mathrm{ppm}(4.85 \mathrm{~g})$ as compared to control (1.02 g). This might be because of higher mobilization of water, nutrient uptake capacity and its transportation by gibberellin than cytokinin which has resulted into more production of photosynthetic products and translocation into various parts of the plant. Similar finding Lay et al. (2013) ${ }^{[10]}$ also reported similar results that Carica papaya L. seeds treated with $\mathrm{KNO}_{3}$ 
at $0.5 \%$ for 48 hours resulted in the highest seedling fresh and dry weight. Seedling vigour was recorded highest (2059.42) in seeds treated with $\mathrm{KNO}_{3} 1 \%\left(\mathrm{~T}_{5}\right)$. As seedling vigour is dependent on germination percentage and seedling length, the seeds treated with potassium nitrate had highest per cent of germination and also recorded the highest height. Abdelgadir et al. (2012) ${ }^{[1]}$ reported that seeds treated with KNO3 for 24 hours produced heavier and longer seedlings which resulted in increased vigour indices of seeds of Jatropha curcas. The results agree with the report of Yogananda et al. (2004) [18] also observed the highest seedling vigour index in bell pepper cv. California seeds treated with $1 \% \mathrm{KNO}_{3}$ in which the mobilization of sugar substrates occurred during the initiation of germination and also it has involved in catalytic activity and break down of complex substances into simple forms such as glucose, amino acids and fatty acids.

Finally, it could be concluded that the higher germination, growth parameters, seedling vigour and survival percentage of seedlings could be obtained by application of $1 \% \mathrm{KNO} 3$ for 10 minutes (soaking time) in Papaya.

Table 1: Effect of seed treatments on germination of papaya (Carica papaya L.) cv. Red Lady

\begin{tabular}{|c|c|c|c|}
\hline Treatment & Number of days taken for germination & Germination percentage (\%) & Survival percentage (\%) \\
\hline T1- Water soaking & 10.78 & 64.98 & 81.03 \\
\hline T2- Hot water treatment & 10.15 & 68.82 & 82.72 \\
\hline T3- GA3 500 ppm & 6.52 & 92.26 & 91.66 \\
\hline T4- IBA 100 ppm & 7.31 & 88.62 & 89.97 \\
\hline T5- KNO3 (1\%) & 5.60 & 96.10 & 93.15 \\
\hline T6- Thiourea (1\%) & 9.01 & 76.31 & 86.00 \\
\hline T7- Vermiwash (20\%) & 9.64 & 72.95 & 84.31 \\
\hline T8- Panchagavya (3\%) & 7.97 & 84.78 & 88.38 \\
\hline T9- Cow dung slurry & 8.52 & 79.93 & 77.68 \\
\hline T10- Control & 11.26 & 61.12 & 2.80 \\
\hline S. Em \pm & 0.30 & 2.62 & 5.80 \\
\hline CD at 5\% & 0.62 & 5.47 & \\
\hline
\end{tabular}

Table 2: Effect of seed treatments on growth parameters of papaya (Carica papaya L.) cv. Red Lady

\begin{tabular}{|c|c|c|c|}
\hline Treatment & Seedling height $(\mathbf{c m})$ & Number of leaves & Stem girth (mm) \\
\hline T1- Water soaking & 10.70 & 5.75 & 1.55 \\
\hline T2- Hot water treatment & 12.13 & 6.38 & 1.76 \\
\hline T3- GA3 500 ppm & 20.21 & 9.40 & 3.28 \\
\hline T4- IBA 100 ppm & 19.00 & 10.03 & 2.45 \\
\hline T5- KNO3 (1\%) & 21.43 & 10.56 & 3.45 \\
\hline T6- Thiourea (1\%) & 14.94 & 7.65 & 2.20 \\
\hline T7- Vermiwash (20\%) & 13.55 & 7.02 & 2.79 \\
\hline T8- Panchagavya (3\%) & 17.78 & 8.76 & 2.99 \\
\hline T9- Cow dung slurry & 16.36 & 8.15 & 1.99 \\
\hline T10- Control & 9.15 & 4.72 & 1.38 \\
\hline S. Em \pm & 0.54 & 0.27 & 0.08 \\
\hline CD at 5\% & 1.12 & 0.56 & 0.18 \\
\hline
\end{tabular}

Table 3: Effect of seed treatments on growth parameters of papaya (Carica papaya L.) cv. Red Lady

\begin{tabular}{|c|c|c|c|c|}
\hline Treatment & Root length $(\mathbf{c m})$ & Number of lateral roots & Total fresh weight of seedling (g) & Seedling vigour \\
\hline T1- Water soaking & 4.95 & 7.64 & 1.60 & 695.29 \\
\hline T2- Hot water treatment & 5.50 & 8.52 & 2.06 & 834.79 \\
\hline T3- GA3 500 ppm & 8.72 & 13.55 & 4.85 & 1864.57 \\
\hline T4- IBA 100 ppm & 8.15 & 12.70 & 4.23 & 1683.78 \\
\hline T5- KNO3 (1\%) & 9.20 & 14.24 & 5.02 & 2059.42 \\
\hline T6- Thiourea (1\%) & 6.53. & 10.25 & 2.90 & 1140.07 \\
\hline T7- Vermiwash (20\%) & 6.09 & 9.39 & 2.53 & 988.47 \\
\hline T8- Panchagavya (3\%) & 7.60 & 11.84 & 3.77 & 1507.39 \\
\hline T9- Cow dung slurry & 6.98 & 10.98 & 3.35 & 1307.65 \\
\hline T10- Control & 3.90 & 6.60 & 1.02 & 546.71 \\
\hline S. Em \pm & 0.23 & 0.37 & 0.12 & 46.16 \\
\hline CD at 5\% & 0.49 & 0.76 & 0.24 & 96.29 \\
\hline
\end{tabular}

\section{Reference}

1. Abdelgadir HA, Kulkarni MG, Arruda MP, Van Staden J. Enhancing seedling growth of Jatropha curcas - A potential oil seed crop for biodiesel. S. Afr. Bot. 2012; 78:88-95.

2. Anburani A, Shakila A. Influence of seed treatment on the enhancement of germination and seedling vigour of papaya. Acta Horticulturae. 2010; 851:295-98.

3. Anonymous. NHB, Database, Gurgaon, Haryana, 201819. www.NHB.com.in.
4. Arjun MP, Mathad JC, Malshe KV. Effect of pre-soaking chemicals on germination and subsequent seedling growth of papaya (Carica papaya L.) cv. Solo. International Journal of Chemical Studies. 2017; 5(4):1812-1816.

5. Babu GC. Performance of groundnut under different levels of pod grading, plant population and seed invigoration. M.Sc. (Ag.) Thesis, Andhra Pradesh Agricultural University, Hyderabad, 1992. 
6. Chacko EK, Singh RN. The effect of GA on the germination of papaya seeds and subsequent seedling growth. Trop. Agric. Trin. 1966; 43:341-346.

7. Dhankhar DS, Singh M. Seed germination and seedling growth in aonla (Phyllanthus emblica Linn.) as influenced by gibberellic acid and thiourea. Crop Res. 1996; 12(3):363-366.

8. Dwivedi DH, Singh S, Singh N, Kumar P. Effect of plant bioregulator and chemical treatment on germination of papaya (Carica papaya L.) Cv. Pusa Nanha. Prog. Hort. 2015; 47(2):250-253.

9. Gao N, Cui G, Lai Y, Zheng S, Li J, Wang J et al. Effects of different treatments on the germination of Oriental lily seeds. Acta Agriculturae Universitatis Jiangxiensis. 2011; 33(4):660-664

10. Lay P, Basvaraju GV, Sarika G, Amrutha N. Effect of seed treatments to enhance seed quality of papaya (Carica papaya L.) cv. surya. Greener Journal of Biomedical and Health Science, 2013; 2(3):221-225.

11. Mayer AM, Poljakoff-Mayber A. The Germination of seeds, 4th edn. Pergamon Press, Oxford. 1989.

12. Panse VG, Sukhatme PV. Statistical methods for Agricultural workers. ICAR, New Delhi. 1985, 381.

13. Prasad VR. Effect of presoaking treatment with chemicals on germination, growth and yield of low quality Sorghum, Maize and Sunflower seeds. Doctoral diss, ANGRAUACH: Genetics and Plant breeding, 1993.

14. Purbey SK, Meghwal PR. Effect of pre-sowing seed treatment on seed germination and vigour of aonla seedlings. Res. Crops. 2005; 6(3):560.

15. Reyes MN, Perez A, Cuevas J. Detecting endogenous growth regulators on the sarcotesta, selerosta, endosperm and embryo by paper chromatography on fresh and old seeds of two papaya varieties. Journal of Agriculture University of Puerto Rico. 1980; 64(2):164-172.

16. Rezvani M, Zaefarian F, Amini V. Effects of chemical treatments and environmental factors on seed dormancy and germination of shepherd's purse (Capsella bursapastoris L. Medic.). Acta Botanica Brasilica. 2014; 28(4):495-501.

17. Yahiro M. Effects of seed pre-treatments on the promotion of germination in papaya (Carica papaya L.). Memories of the Faculty of Agriculture. Kagoshima University. 1979; 15:49-54.

18. Yogananda DK, Vyakaranahal BS, Sekhargouda M. Effect of seed invigoration with growth regulators and micro nutrients on germination and seedling vigour of bell pepper cv. California wonder. Karnataka Journal Agriculture Science. 2004; 17(4):811-813. 